Journal of Architectural Research and Education (JARE)

Vol. 1 (2) 107-122

@M. Ridha Alhamdani, Dian Perwita Sari. 2019

DOI: 10.17509/jare.v1i2.22301

\title{
Performance Evaluation of Pontianak Kapuas Indah Market from Architecture and Behaviour Aspect
}

\author{
M. Ridha Alhamdani ${ }^{1}$, Dian Perwita Sari² \\ ${ }^{1}$ Department of Architecture, Tanjungpura University, Indonesia \\ ${ }^{2}$ Department of Architecture, Pontianak State Polytechnic, Indonesia \\ ${ }^{1} \mathrm{Jl}$. Profesor Dokter H. Hadari Nawawi, Pontianak, Indonesia \\ 2 Jl. Ahmad Yani 78124, Pontianak, Indonesia \\ Corresponding Author: mridhaalhamdani@gmail.com \\ dianperwita.ars@gmail.com
}

Received: 5 Oktober

2019

\author{
Article History: \\ Revised: 15 November Accepted: 20 Desember \\ 2019
}

Available online: 31 Desember

2019

Abstract - The Government of Pontianak City's efforts in carrying out the mission of creating quality and representative urban infrastructure is a program to improve and assets development of public facilities. It formed of infrastructure and is currently functioning for public service facilities. One of the assets of this public facility is the 40-years-old Pontianak Kapuas Indah Market, located right on the edge of the Kapuas River. This market in its past is known as the Kapuas Indah Shopping Center, it experienced decreasing quality or function shifting, along with the development of cities that grow the new economic areas that are more modern and millennial. At present, this market is still functioning but only limited to certain consumer market segments. Therefore, it is necessary to have to repair and developing in order to be able to function optimally as the city public asset. In order to improve and redevelop the facilities in this market, the post-occupancy evaluation method needs market physical facilities and infrastructure, these steps for developing physical facilities meet more targets in the future. This study uses qualitative exploratory methods with an investigative approach to analyze the aspect of behavior users of buildings and its functions of the Kapuas Indah Market and from these results of the analysis determined the problem handling strategies in it. The results of this study are strategies and recommendations for improving functional performance with regard to compatibility or suitability, namely the concept of statements about the quality of the relationship between user activities and the physical building of the Kapuas Indah Market. Second, adjustments related to human activities in the room, behavior related to equipment and possibilities of adaptation to the demands of building physics and the natural environment around the Kapuas Indah Market.

Keyword: behavior; function; performance.

\section{Introduction}

The concept of building performance is the basis of philosophy and the theoretical basis of Post Occupancy Evaluation which includes the aspects of behavior, quality, and how it is measured and evaluated carefully (Preiser,1988 in Syafriyani, 2015). Furthermore, Preiser stated the concept of performance in a building using the principles of measurement, comparison, evaluation, and feedback. These are part of a systematic approach to improve the quality of the environment of a building where it includes variations of existing mechanisms to make a building more responsive to the desired function and to the needs of building users (Syafriyani, 2015). The aspect criteria basis of Post Occupancy Evaluation are divided into 3 as follows (Preiser, 1998) and (Sudibyo, 1989 in Natalia, 2019):

1. Functional Aspect

The functional aspects in question are all aspects of the building (built environment) that directly support the activities user with all their attributes in both groups and individuals. Spaces formers such as walls, floors, and ceilings indirectly affect user activity. Spatial and circulation also affects user activity and the occurrence of overall functions. 


\section{Technical Aspect}

The condition of building physic will be affecting its user e.g. in amenities, building safety and have a long life span (Preiser, 1988 in Setiawan and Haryadi, 2010). These are related to building conditions involve the structure, ventilation, sanitation and safety of the building and its buffer system.

3. Behavior Aspect

Behavior aspects relate to the users' activities with their physical environment. Behavior evaluation relates to the social and psychological well-being of the user who influences the design of the building. Behavior problems that need to consider such as cognition and orientation, privacy and interaction, perception, proximity and territoriality, image and meaning.

Merrit and Amrose (1990) state that there are several main elements in buildings that can consider for planning and evaluation, likely:

1. Structure and construction;

2. Circulation;

3. Control of buildings;

4. Plumbing;

5. Electrical systems.

In normative regulation considerations, an architectural review emphasizes several aspects, such as the building appearance that is harmony with the environment, good interior planning, and the building balance with the surrounding environment. In its design and development, a building as an architectural work occupies a certain location complete with systems, tools, and spaces that function to support human activities. Summarized from Gray dan Hughes (2001) architecture judgment and evaluate based on its contribution to the visual enjoyment observer, both from the overall appearance and from the space and light present in space.

Tunstall (2006) also gives several considerations in architectural design that buildings are generally not like mass products that can replace quickly. The building was created as a commercial proposition, built according to the specific requirements from the client, as the large product, expensively and cannot be easily withdrawn for repair. Tunstall added that the ease of the building dividing into consideration of horizontal and vertical relations, accessibility, and complementary building facilities. In horizontal circulation, it is necessary to consider the movements of people or occupants in the building. In addition, people and goods should consider regulating circulation channels so that their movements become easy and efficient and eliminate frustration. Criteria for behavior aspects also play an important role in building performance. Behavior evaluation is about how social welfare and user psychology influence by building design. Some elements of behavior that need to consider are interactions, perceptions, images, orientation, and privacy (Syafriani, 2015). In line with Barker at Popov dan Chompalov (2012) in Fajarwati (2016) said that the main point in the study of setting behavior is a group of people, activities, specific places and times.

Pontianak City has made improvements in all fields and experienced rapid development progress, both in infrastructure, the physical environment, and community development. One of the efforts of the Pontianak City Government in carrying out its mission of creating a quality and representative urban infrastructure is a program to revamp and develop assets of public facilities. The assets are in the form of infrastructure facilities that are currently functioning for public service facilities.

Kapuas Indah Market is one of the public service assets, an old market in Pontianak City, inaugurated by President Soeharto on October 23, 1978, to coincide with the anniversary of Pontianak City. At first, the function of this market was as a complex shopping center equipped with several supporting facilities such as children's play areas and cinemas by carrying the modern concept in its time, this can be seen from the zoning planning, access and vertical circulation using an escalator, geometric building form, use of colors and new materials on building facades. But now the existence of the market experience degradation function, along with the development of the City which growing with a lot of new and modern market centers or economic zones, such as supermarkets that began to emerge in the 1990s and Mall areas in the 2000s. 
The physical condition of the market building is starting to obsolete. Some elements of the building damaged and malfunctioning, dirty and shabby impression and some inadequate market infrastructures play a role in decreasing market function and the stigmatized consumer market share only for the lower middle class.

Responding to these problems, the Pontianak City Government conducting several traditional market arrangements as part of the assets of public facilities that serve all kinds of living needs of the city community. One of them is the improvement and arrangement of the Kapuas Indah Market located on the edge of the Kapuas River. This market still functioning but only limited to certain consumer market segments. It needs to improve and rebuilt so that it can function optimally as an asset of public facilities. To improve and redevelop the facilities in this market, a post-occupancy evaluation method is needed for market physical facilities and infrastructure, so that the steps to develop physical facilities can meet their targets in the future.

The purpose of this study was to provide recommendations and strategies for improving the performance of the Kapuas Indah Market building in terms of building functions aspect and user behavior. Besides, to find out the gap between the existing performance of physical facilities in the Kapuas Indah Market and analyze architectural requirements whose quality and capacity needed to be developed in the future.

\section{Methodology}

\subsection{Research Location}

The research location is the Kapuas Indah Market, located on JL. Captain Marsan, Darat Sekip, Pontianak Kota, Pontianak City, West Kalimantan. This building has a length of $60 \mathrm{~m}$ and a width of $50 \mathrm{~m}$ with BCR up to $80 \%$ and east building boundary line of $10.50 \mathrm{~m}$ from the middle of $\mathrm{Jl}$. Captain Marsan. Kapuas Indah Market consists of three floors, with each height of $3 \mathrm{~m}$.

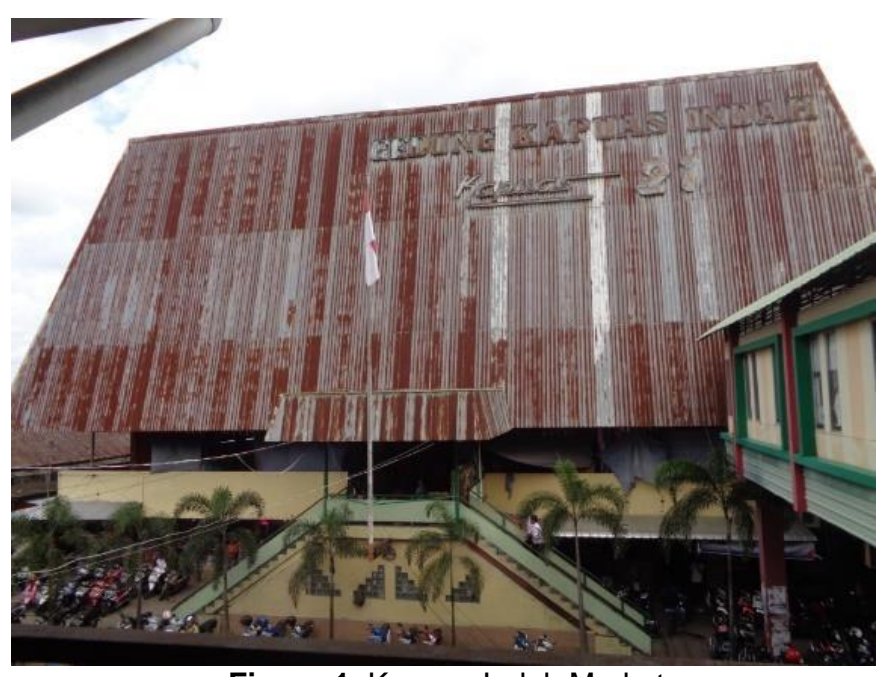

Figure 1. Kapuas Indah Market (Source: author).

\subsection{Research Methode}

The approach of the research method used is a qualitative research method using investigative occupational evaluation methods. According to Creswell (2007) in Syafriani (2015), qualitative research is methods to explore and understand the meaning that some individuals or groups of people ascribe to social or humanitarian problems.

Regarding the method of building evaluation, refer to the Post Occupancy Evaluation and Building Performance Evaluation guidelines issued by the Royal Institute British Architect (RIBA, 2016). Causal relationships can result from several "systems" in a building, such as the activities or behavior of occupants, the function or use of buildings, the comments of occupants and the use of resources. 


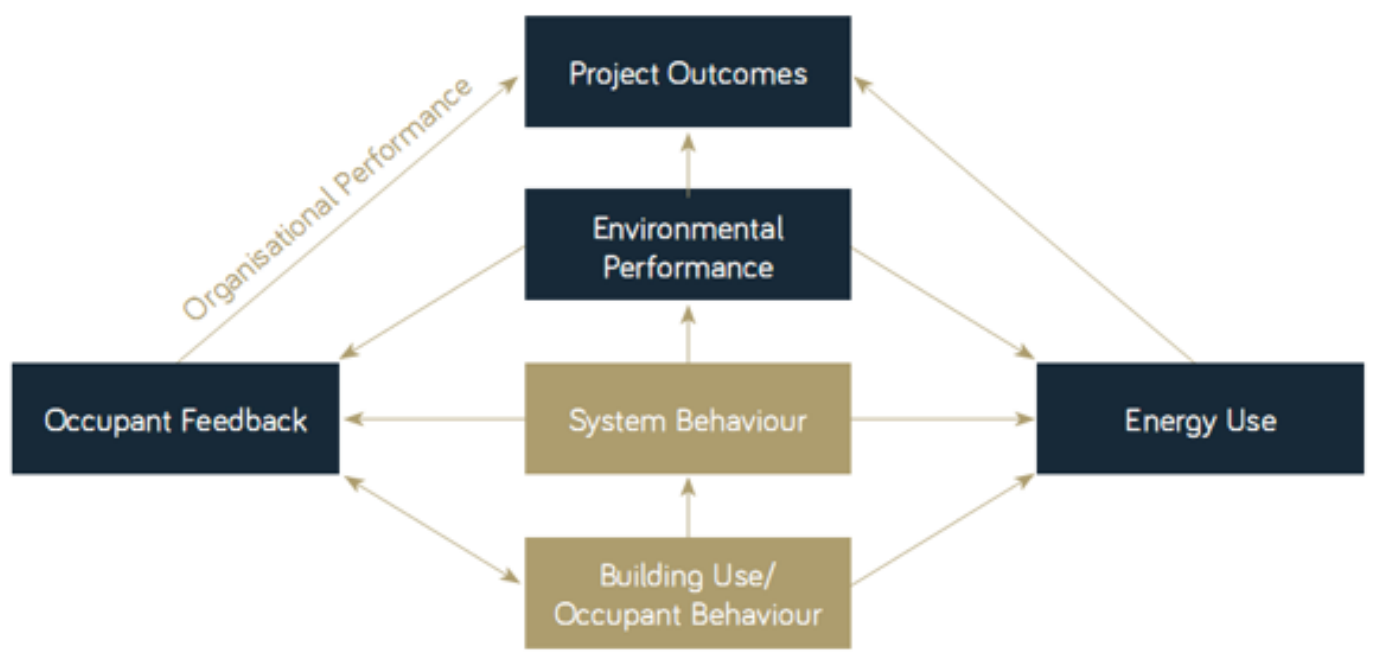

Figure 2. connection of systems in building evaluation (Source: RIBA, 2016).

In general, research activities using the post-occupancy evaluation method are carried out in several steps, namely:

- Collecting building regulations and standards

- Arranging categories based on the RIBA POE guidelines.

- Arranging categories based on building regulations and standards that contain elements of architectural requirements

- Collecting data on existing building plans (as-built drawings).

- Collecting data through observation, surveys, interviews and technical calculations.

- Processing data through categorization, coding, visualization, illustration, and statistical data.

- Data analysis through comparison of existing standards and conditions through several categories of assessment parameters.

- Analysis and discussion of the assessment result in each category or among the requirements elements.

- Drawing conclusions and recommendations on the results of building evaluations.

The criteria for building evaluation shown in the table below.

Table 1. Building Evaluation Criteria

\begin{tabular}{lll}
\hline$N_{0}$ & \multicolumn{1}{c}{ Laws and Regulations } & Post Occupancy Evaluation by RIBA \\
\hline 1 & Architecture Requirements & Building function and behavior \\
\hline 2 & Safety Requirements & Energy use \\
\hline 3 & Health Requirements & Building system \\
\hline 4 & Comfortable Requirements & Building environment performance \\
\hline 5 & Convenience Requirements & Building construction \\
\hline
\end{tabular}

(Source: author)

This research focuses on the elements of building architectural requirements namely building functions and behavior. A qualitative research approach is carried out in an investigative way by comparing the existing conditions of the existing planning system in buildings with building standards, literature or regulations from both human factor standards and building technical standards (Blyth and Gilby, 2006).

The next stage in this research is to conduct a behavior analysis through Behavior Mapping. Behavior mapping is one of the survey techniques for the study of behavior architecture. According to Sommer (1986) in (Siregar, 2017) behavior mapping can be illustrated in the form of sketches or diagrams about an area where humans perform various activities, their own goal is to describe the 
behavior on the map, identify the type and frequency of the behavior, and show the relationship between user behavior with specific spaces.

Behavior mapping methods use the results of field surveys to develop Kapuas Indah Market design results later. Behavior mapping assists by using space syntax analysis. Johaness (2014) in Siregar (2017) states that space syntax has three dimensions of calculation or simulation analysis that includes connectivity, integrity, and intelligibility. Space syntax with its three dimensions then becomes the standard in research on architectural and urban space configurations assisted by software in several platforms (Siregar, 2014).

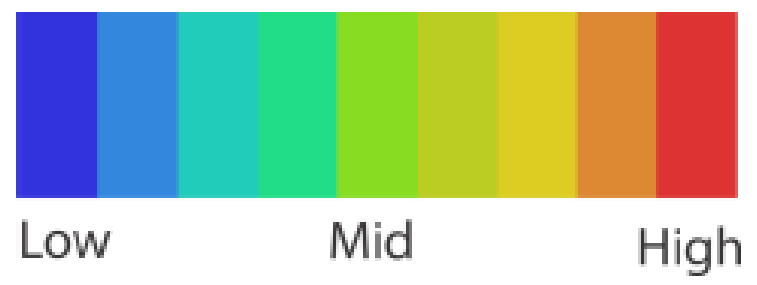

Figure 3. Value Parameter in Depthmap v.10 software (Source: author).

The highest measurement of space syntax is intelligibility. Intelligibility value shows the correlation level between local-connectivity with integrity. Thus, full intelligibility is a measurement of the structure of a spatial configuration. Intelligibility measured by using correlation analysis of two aspects by showing a diagram and a value explanation. The coefficient correlation of product person moment $(R)$ produces a correlation value in the form of numbers in the range 0 (lowest) to 1 (highest). Where the value 0 indicates there is no correlation at all in space or it is not easy to achieve, space relations, and interactions (Siregar, 2017), while a value of 1 means a space configuration that is very easy to achieve.

Table 2. Intelligibility Evaluation Parameter

\begin{tabular}{l|l|l|l}
\hline \multicolumn{4}{c}{ The evaluation parameters of effectiveness space } \\
configuration \\
\hline Parameter Number & $0-0.4$ & $0.5-0.7$ & $0.8-1.0$ \\
\hline Number Adjective & Poor & Fair & Good \\
\hline
\end{tabular}

(Source: author)

\section{Results And Discussion}

\subsection{Architectural Performance of Kapuas Indah Market}

The overall appearance of the Kapuas Indah Market has a color and proportion in harmony with the surrounding buildings. This building is in the old city of Jalan Tanjungpura, has a high roof according to its facade. However, now the color of the paint has begun to fade and damage. Many parts of the building to peel and mossy because of the age ( \pm 40 years). The proportions of the building to be in harmony because it adjusts with surrounding buildings that have a height of two to three floors.

Building entrance access is strategical, can see clearly, and direct access from the parking and main road. There are three entrances access, first in front of the building, in the next of building, and behind the building for visitor access from the Kapuas River dock. 


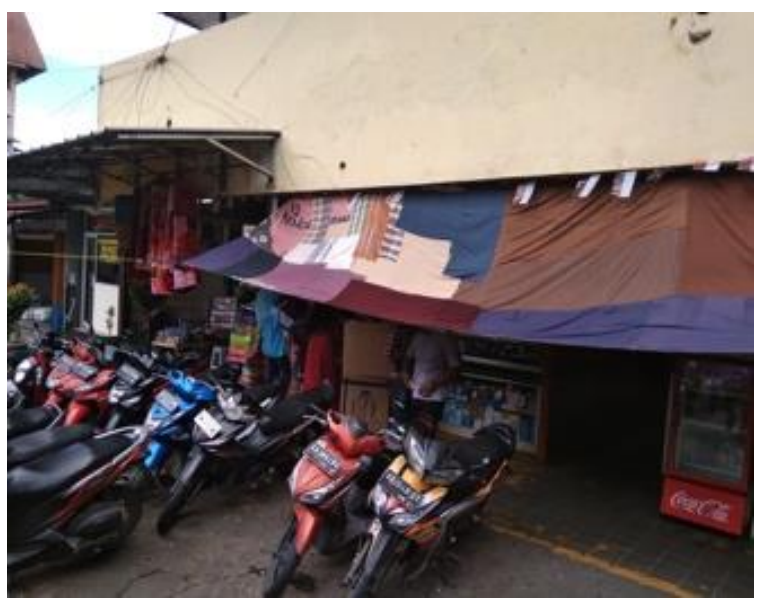

Figure 4. Building access from the side entrance (Source: author).

The building has a corridor with $2 \mathrm{~m}$ width and $60 \mathrm{~m}$ length. Some parts of the corridor are very narrow because sellers make corridor as stall area. There are stairs and escalators to access the building, but at this time, the condition is not feasible because there are no stair railings and the escalators not working properly. The walls of the building have also not maintained and are peeling off.

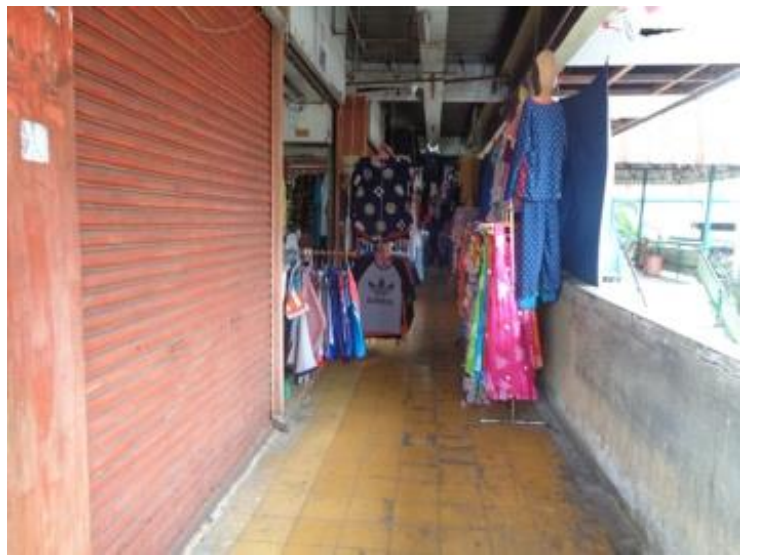

Figure 5. building corridor situation (Source: author).

The main supporting facility is the shop. The area of shops in the market consists of two types, namely $2 \mathrm{~m} \times 2 \mathrm{~m} \times 3 \mathrm{~m}$. This area is not ideal for seller' activities. This happens because one seller has more than one shop combined. Besides, sellers place or hang merchandise in the corridor to make buyers get less free to move. The building supporting facilities are parking areas, toilets, washing areas, rubbish bins, and prayer rooms. Whereas supporting service facilities consist of places to eat/drink, security posts, and information places. Kapuas Indah Market does not provide facilities for people with disabilities, making it difficult for visitors with disabilities to shop at this market. On every floor in the building, there is access or opportunity to view out of the building towards the Kapuas River. The visual comfort can feel evenly and clearly on each floor.

The first-floor condition with maximum floor damage level is $25 \%$. The condition of some terrazzo tiles cracked, the color was faded and eroded. The wall materials used in the building are multiplex and bricks coated with plaster and painted. The damage rate for the wall is $25 \%$. Damage in the form of paint that has peeled and faded stucco has a bumpy or uneven texture, and there are broken walls. The ceiling damage level is $5 \%$. The condition of the sills, doors, and windows is still in good condition and well maintained, because the seller who owns the shop is aware of the safety of their merchandise, so the door is sufficiently maintained. There are no windows in the shop section with a $5 \%$ damage rate. 


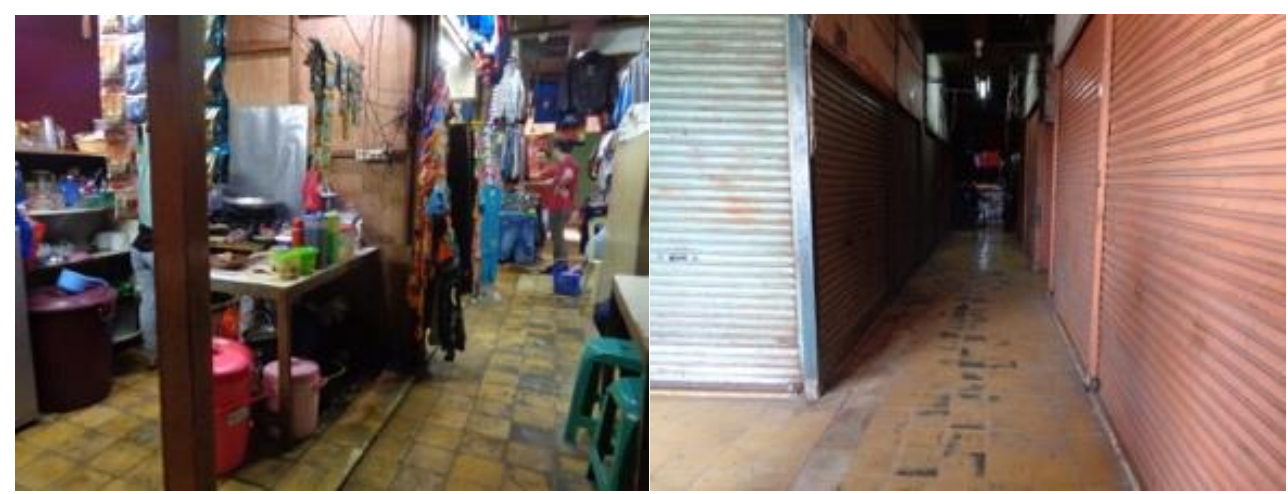

Figure 6. 1st floor condition

(Source: author)

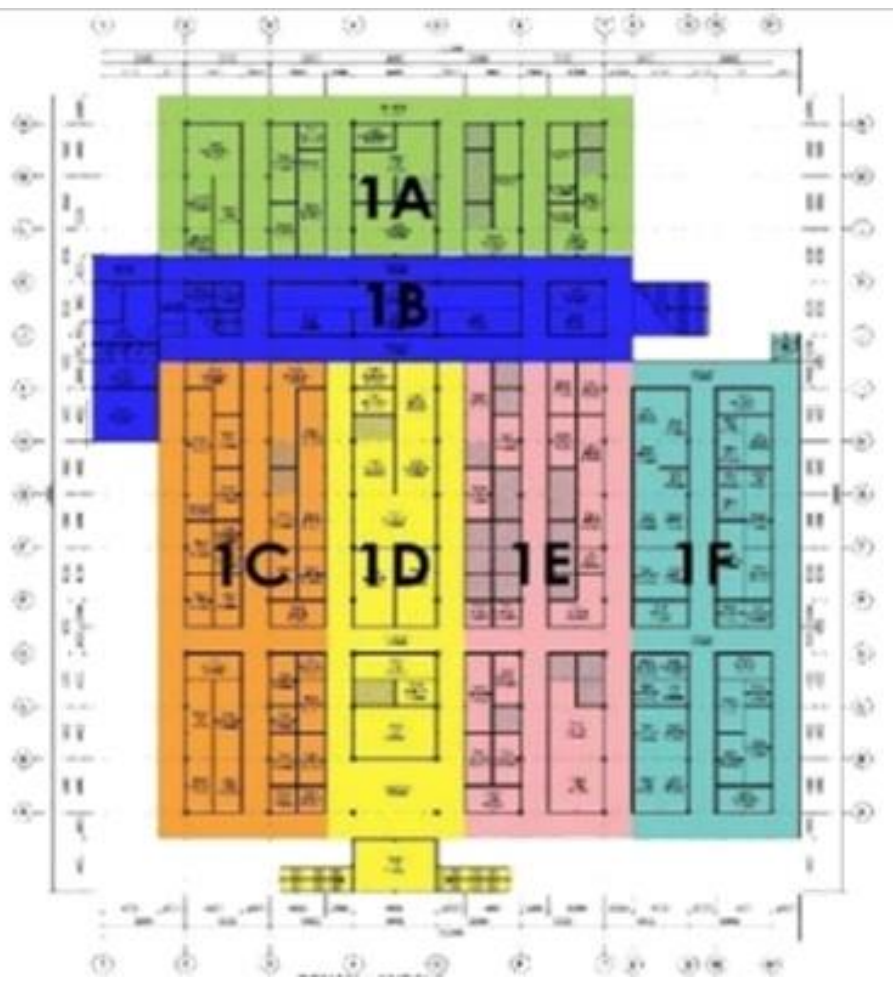

Figure 7. 1st-floor plan

(Source: author)

On the second floor, the damage rate is above $25 \%$. The condition of some terrazzo tiles cracked, the color was faded and eroded. On the floor connection, the terrazzo tiles appear to separate from the old building and a new one. That happened because of the decline in the foundation and the absence of dilation at the floor connection of the building. The maximum wall damage rate is $25 \%$. Damage consists of peeling and fading paint, bumpy texture, and there is a broken wall. The condition of the ceiling cover on the second floor is good with a $25 \%$ damage rate. The damage happened because of the leak at the connection part of the old and new building. The condition for the door located in non-occupied is not maintaining, there are parts of the door that are damaged and rusty. There is no window in the shop section. The maximum damage for door and windows is $25 \%$. In some shops that not occupy or only to use as warehouses, the condition of the lock damage and many of them are lost. 


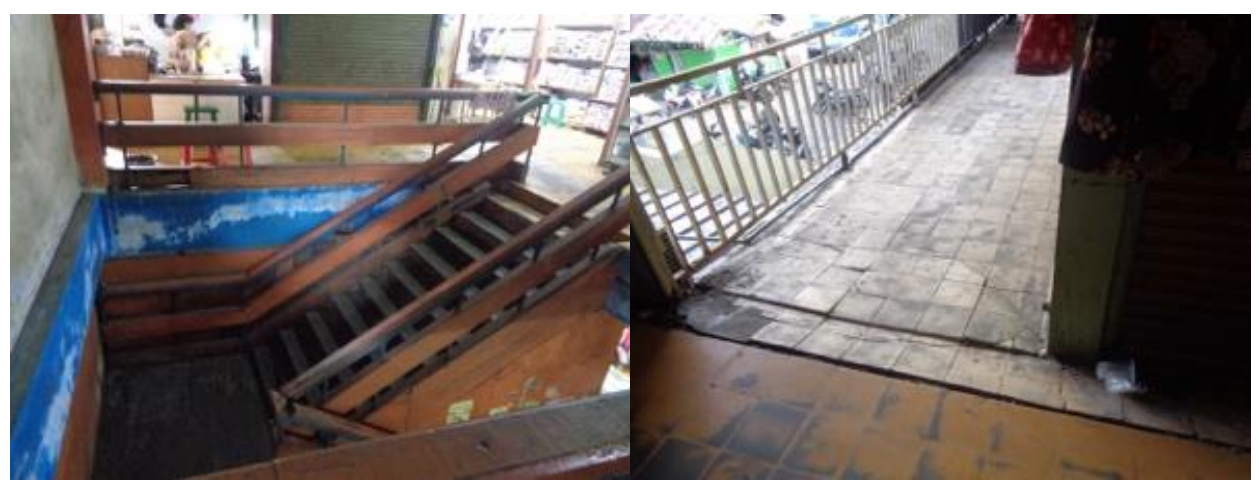

Figure 8. 2nd floor condition (Source: author)

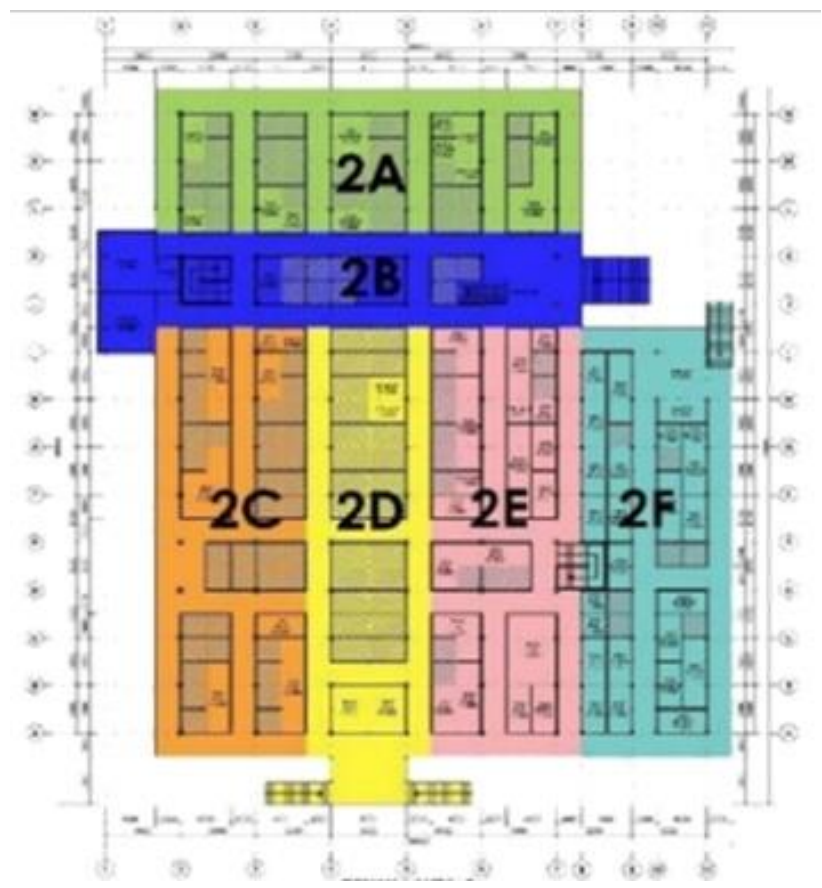

Figure 9. 2nd-floor plan

(Source: author)

The 3rd-floor using concrete that covered with grass carpet, because it was functioning as a futsal court. Ceramics using in the toilet structure, and bondex in the corridor. The level of floor damage above $25 \%$ (i.e. $90 \%$ ). The damage was almost on the entire floor because it has not used and not occupied for \pm 10 years. The wall construction is multiplex and brick, which is covering by plaster and paint, and ceramics in the toilet area. The damage rate for wall construction is above $25 \%$. The condition of the ceiling cover is very poorly with a level of damage above $25 \%$. Almost all of the ceiling on the third floor has broken, there were only the ceiling frames still installed properly. The condition of the sills, doors, and windows on the third floor almost completely damaged. The damage rate is above $25 \%$ (i.e. $90 \%$ ). The door and window fixtures almost completely damaged and lost too. The door handle and the key are gone. The folding door for the escalator also has damaged and rusted. The condition of the roof cover is still quite good. Damage caused by rusty material and made some parts of the roof leak. Listplank and gutter also not maintained because of the building age, which is already \pm 40 years. 


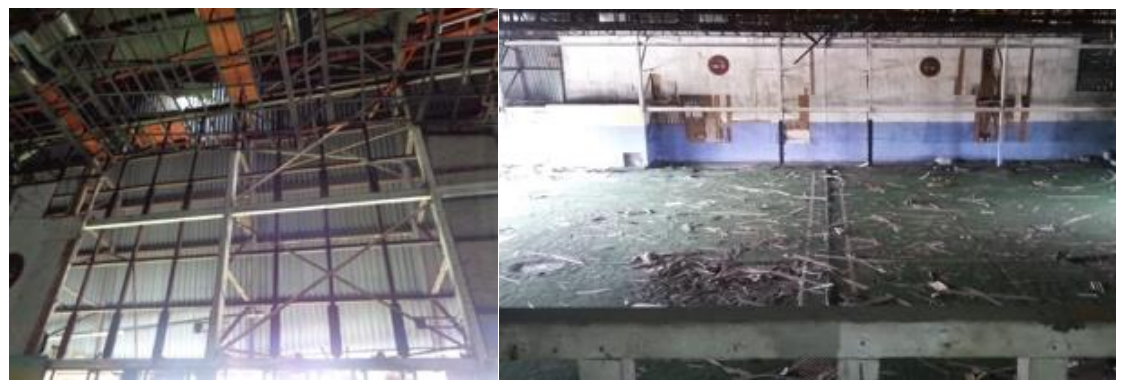

Figure 10. 3rd floor condition (Source: author)

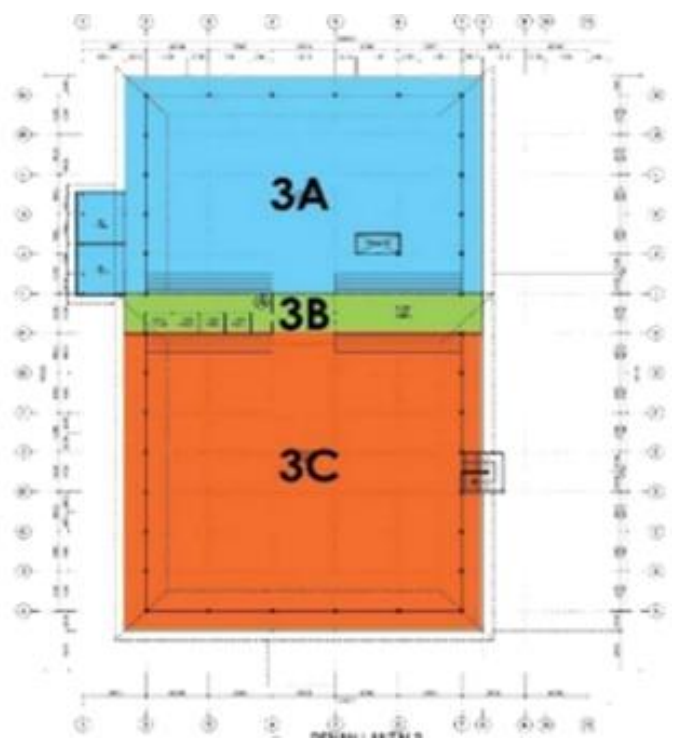

Figure 11. 3rd-floor plan

(Source: author)

\subsection{Analysis of Architectural and Behavior Aspects}

In this section, each condition will calculate in each category of building requirements. In determining the assessment score, carry out by dividing the range of values in the categories GOOD, FAIR, and LESS. With a score range of 95-100 for the GOOD category, 75-95 for the FAIR category, and under 75 for the LESS category. Value categorizing is done with the assumption that building condition is reliably or livable and "almost perfect" to all the completeness of its requirements. The highest value in the GOOD category has a gradation below it. The determination of assessment was finish by physical/sensory observation and measurement using certain measuring devices.

Table 3. Results of Building Requirements Assessment

\begin{tabular}{llll}
\hline \multicolumn{1}{l}{ 1. Building Architectural } & & \\
\hline Observation Appraisal & & \\
\hline No & Parameter & $\begin{array}{l}\text { Assessment } \\
\text { Score }\end{array}$ & $\begin{array}{l}\text { Assessment } \\
\text { Category }\end{array}$ \\
\hline 1 & Building Facade & $\mathbf{9 8}$ & G (GOOD) \\
\hline 2 & Open Space & $\mathbf{5 0}$ & L (LESS) \\
\hline 3 & Building Form & $\mathbf{9 8}$ & G (GOOD) \\
\hline 4 & Insulation Walls & $\mathbf{9 8}$ & G (GOOD) \\
\hline 5 & Ceilling Height & $\mathbf{9 0}$ & F (FAIR) \\
\hline 6 & Toilets & $\mathbf{8 5}$ & F (FAIR) \\
\hline 7 & Outdoor Circulation & $\mathbf{8 5}$ & F (FAIR) \\
\hline 8 & Floors Condition & $\mathbf{8 6}$ & F (FAIR) \\
\hline 9 & Wall Condition & $\mathbf{8 5}$ & F (FAIR) \\
\hline 10 & Ceiling Cover Condition & $\mathbf{9 0}$ & F (FAIR) \\
\hline 11 & Doors/Windows Condition & $\mathbf{9 3}$ & F (FAIR) \\
\hline 12 & Doors/Windows accsesorries & $\mathbf{8 5}$ & F (FAIR) \\
\hline 13 & Roof Cover & $\mathbf{8 5}$ & F (FAIR) \\
\hline 14 & Lisplang and gutters & $\mathbf{7 3}$ & L (LESS) \\
\hline & Building architectural Score & $\mathbf{1 2 0 2}$ & \\
\hline & $\begin{array}{l}\text { Average } \text { Building Architecture } \\
\text { Score }\end{array}$ & $\mathbf{8 6}$ & F (FAIR) \\
\hline & & & \\
\hline
\end{tabular}


In the category of building architecture, the average assessment score reaches 86 and falls into the "FAIR" category. In general, the GOOD rating part is the display parameters of the building and the wall insulation. Whereas the LESS is the parameter of open-space available around the Kapuas Market area. Beyond that, at least in general terms, the average rating shows figures with FAIR categories. The next analysis is to analyze the behavior of building users. Behavior movements on the first, second and third floors have observed to obtain information related to the mapping of the movement of users in this building. From its results than to integrate with the results of space syntax analysis. Space syntax analysis uses the simulation Depthmap v.10 software. The use of simulation with Depthmap obtain by analyzing the layout of space based on the arrangement of the spatial relationship patterns, the results will displayed in the VGA form (visual graph analysis).

On the first floor, the movement of visitors and shop owners to enter the building can be from anywhere, because the access is open. Visitors move to the shops to buy goods while the shop owner moves to his shop to sell and buy.

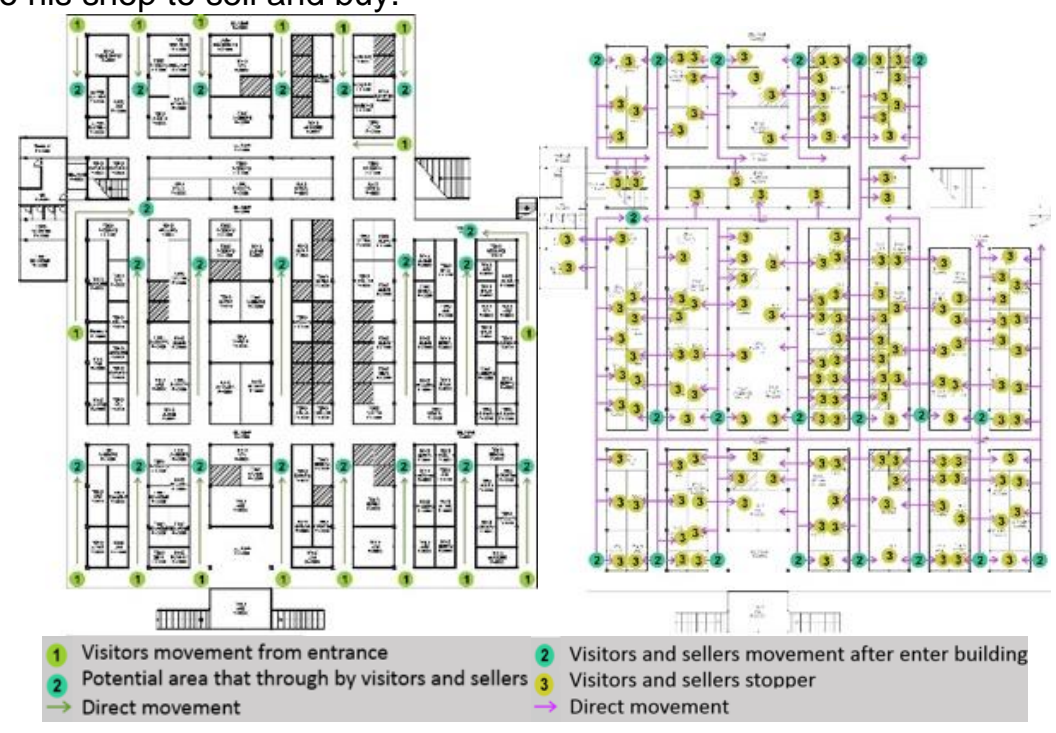

Figure 12. behavior mapping analysis for 1 st floor (Source: author)

On the second floor, the movement of visitors and shop owners limiting by the entrance access in the form of stairs located on the front side and the right side of the building. The next activity is moves to the shops to buy goods and the seller moves to his shop to sell and buy.

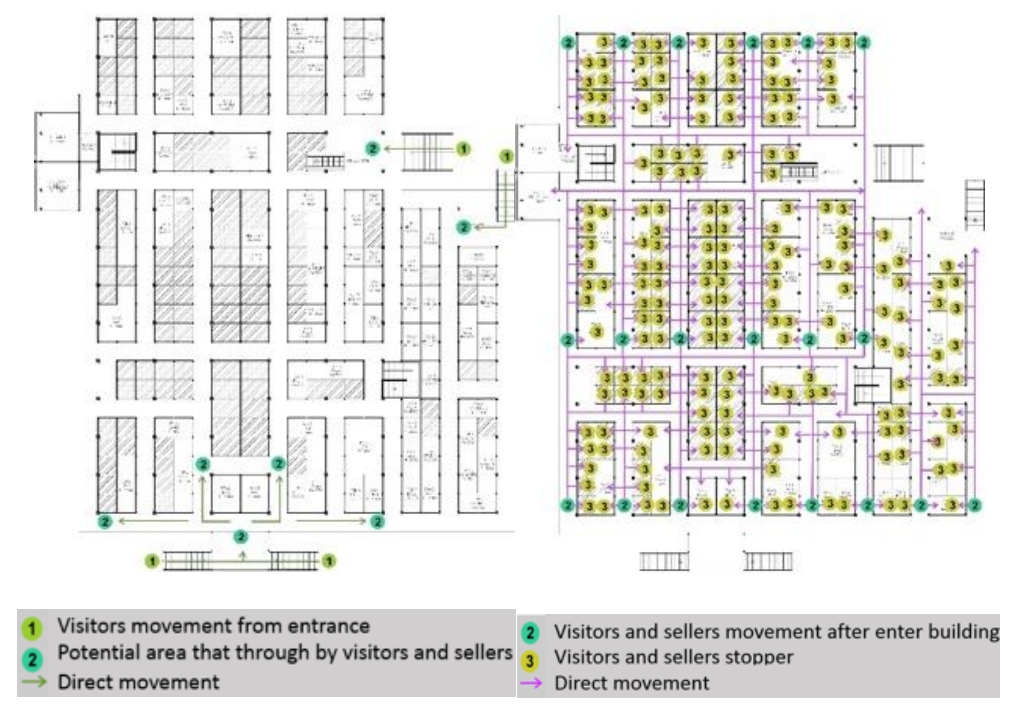

Figure 13. behavior mapping analysis for 2 nd floor (Source: author) 
On the third floor, the visitor's movement only through two main access, the stairs on the right side and the former escalator that no longer used anymore. Visitors and market managers could have passed towards the grandstand. Activities on the third floor while still in use are visitors moving directly to the futsal area via stairs. The building manager moves to the cassette storage room through the stands and management stairs. The manager enters the 3rd-floor area bypassing the same access as the visitor to enter the manager's room but has his access to the playroom and cassette storage.

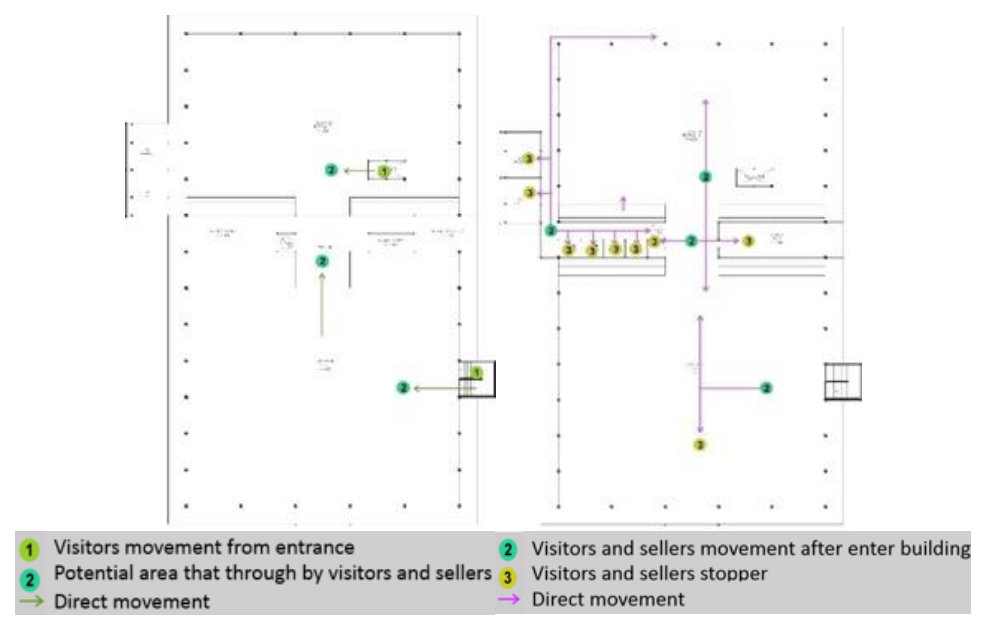

Figure 14. behavior mapping analysis for 3rd floor

(Source: author)

From observations in the field, it shows the flow of visitors, shop owners, and building managers are relatively similar to the path through which is the front corridor area. This makes the building circulation less directional because access to the building is the same. Behavior mapping results in the field correlating with simulation results using syntax space analysis.

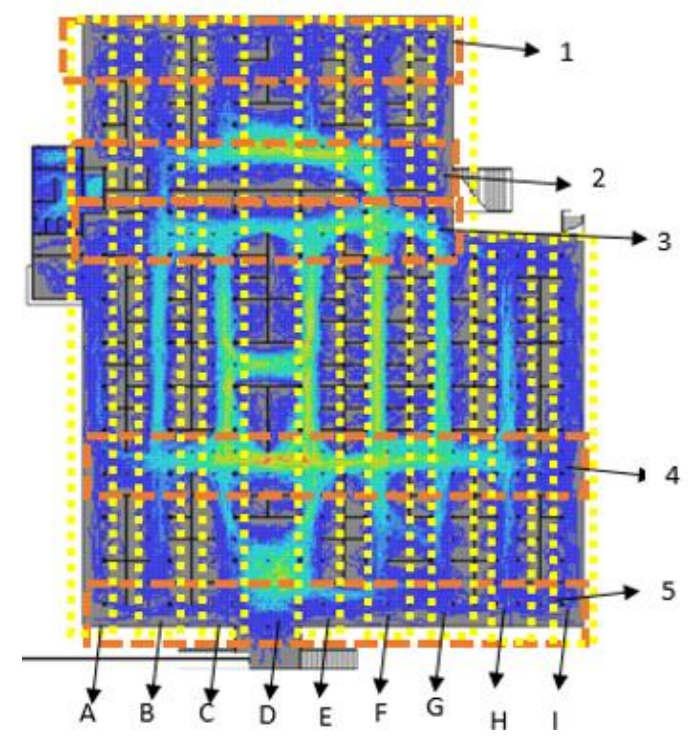

Figure 15. visitor movement analysis at 1st floor (Source: author).

From the first-floor plan figure of the Kapuas Indah market above, it can see the area that is often traversed by visitors are corridor 3, 4, 2, C, E, F and G, D, H, and I. This shows that the central corridors, especially corridors $2,3,4, C, E, F, G$ are easily accessible areas, attract and interesting for visitors. Whereas the corridors on the outer and sub-outer (1, 5, A, B, D, H, I) are not interesting 
to visit even though this area is close to access.

From the analysis of visitor movements on the 2nd floor, it founded that the areas with high movement shown in corridors 2, 3, 4, 5, C, D, E, G. Whereas the areas with low movement are corridors 1, 6, 7, A, B, F, H. Just like the flow of movement on the first floor, the flow of visitors on the second floor tends centered in the middle of the building. The flow of movement at the edge of the corridor tends to be slight. The movement can see in the image below.

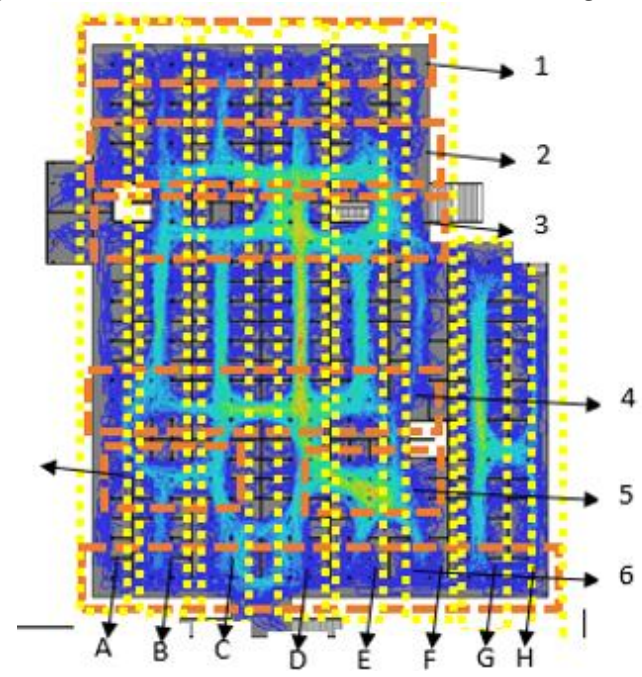

Figure 16. visitor movement analysis at 2 nd floor

(Source: author)

The 3rd-floor area is un-partitioned; the divider is only in the middle for manager access and toilets. From the results of space syntax analysis shows that in the area of the front of the third floor, there is a high concentration of visitor movements, while in the back the low. This caused by the size of the front area that is wider than the back, causing the concentration of movement in the front area.

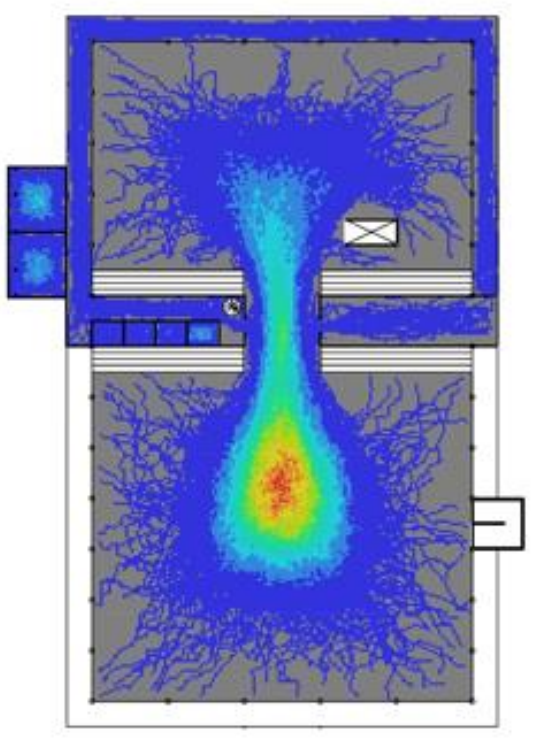

Figure 17. visitor movement analysis at 3rd floor

(Source: author)

After analyzing the flow of movement of building users, the analysis continues to analyze the interconnectedness of space on each floor, namely connectivity, integrity, and intelligibility. Connectivity analysis on the first floor is the relationship between shop spaces connected to the surrounding corridors, a reddish-yellow gradation seen between the access road in the form of corridors that make it as the connecting spaces on the first floor. In integrity analysis, the highest 
integrity in the corridor access lane in the front of the building to the next store, the area has the potential for more space user activity. The results of connectivity and integrity values produce an intelligibility value of $R=0.46669-0.517978$. Where $R$ is the value of intelligibility. When viewed from the parameters of achieving effective space values, the first floor is categorized LESS in the ease of achieving and linking space. The relationship between the three components shown in the figure below.
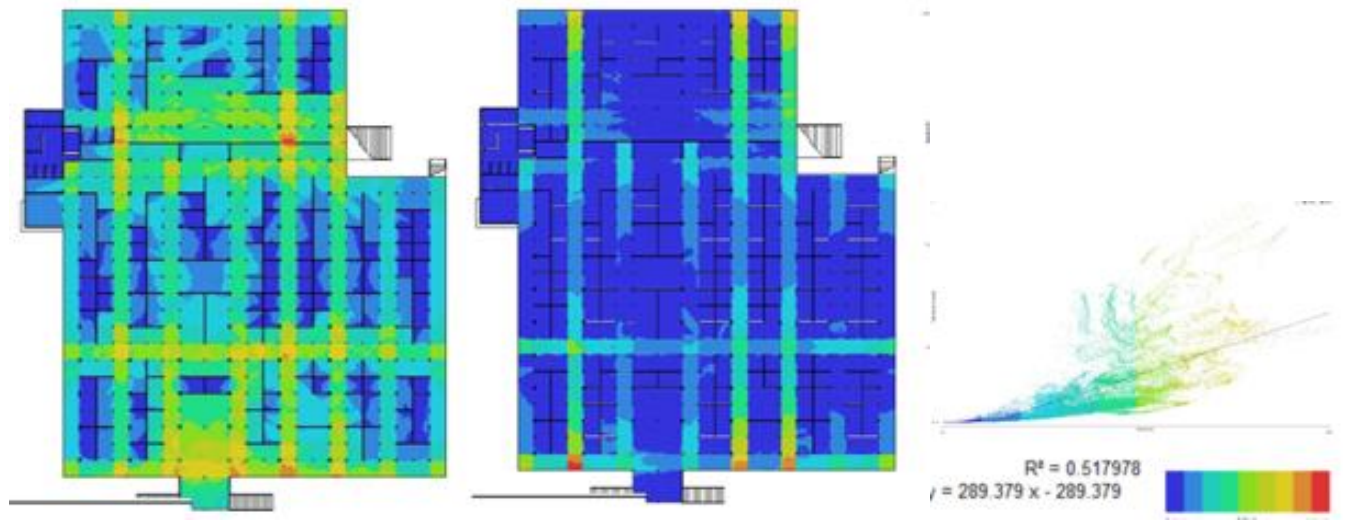

Figure 18. (From left to right) Connectivity, Integrity, Intellibility at 1 st floor (Source: author)

In the analysis of connectivity on the second floor, the relationship between shop spaces connected with the corridors around it, a reddish-yellow gradation seen between the access road in the form of corridors that make connecting spaces in the second floor. The integrity of the second floor found the highest integrity in the central corridor access of the building has the potential for more movement and activities in it. The results of the correlation value of connectivity and integrity produce an intelligibility value of $R=0.470214-0.50085$. When viewed from the parameters of the achievement of effective spatial value, second-floor space is categorized LESS in the ease of achieving and linking space. This can see in the image below.
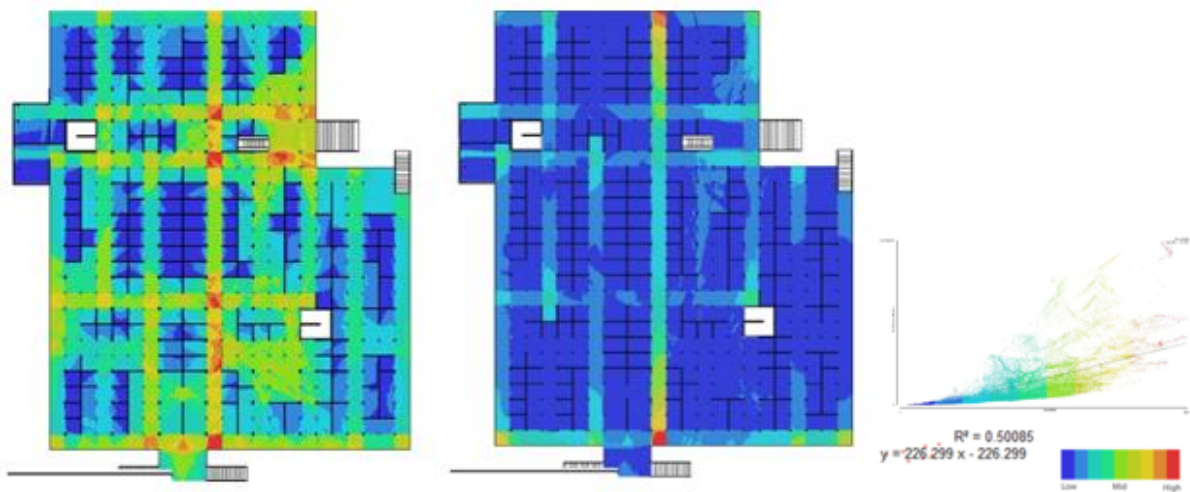

Figure 19. (From left to right) Connectivity, Integrity, Intellibility at 2nd floor (Source: author)

Connectivity analysis of the 3rd-floor of the Kapuas Indah Market which only has 1 corridor in the room to connect 2 areas of the futsal field, the results are a very high connectedness analysis, this caused by the absence of a room divider in this area. The highest connectivity value was in the front area. The integrity analysis Kapuas Indah Market found the highest integrity in the front area of the floor, the reddish color gradation very clearly seen in this area because there is no boundary space, while the space behind it has an integrity value less than front area. The results of the correlation between connectivity and integrity values produce an intelligibility value of $R=0.761905-0.741249$. When viewed from the parameters of achieving effective space values, the third floor of Kapuas Indah Market categorizing FAIR in the ease of achieving and linking space. 

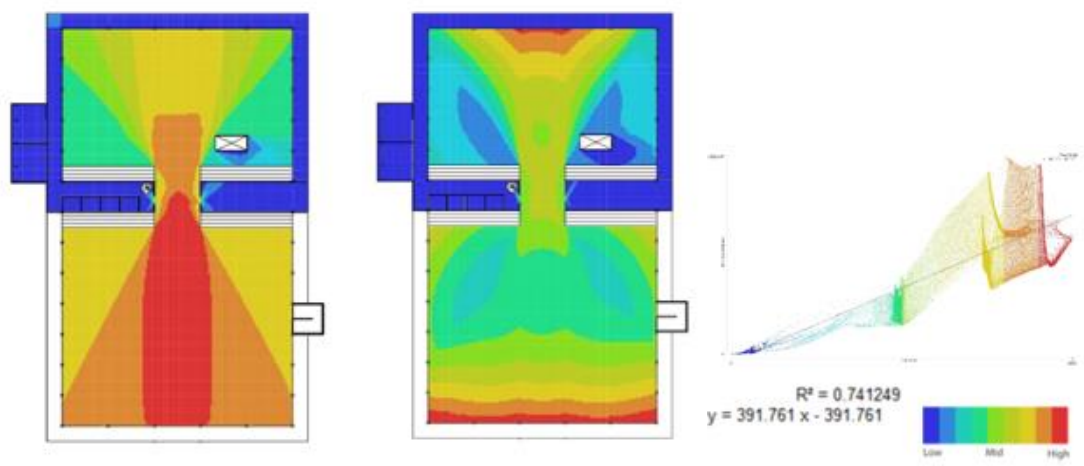

Figure 20. (From left to right) Connectivity, Integrity, Intellibility at 3rd floor (Source: author)

From the analysis of all floors, it is showing that the first and second floors have lower intelligibility values or 0.47 and the third floor is 0.74 . The results of behavior mapping analysis and space syntax analysis can determine or become a starting point to make the configuration of the space to design as well as ideal because they already know the existing crowd point. Therefore, the results of space syntax analysis and behavior mapping can provide a solution in the design that requires the concept of flexibility and space efficiency that has very high activity.

Next, the interview activity using media (instrument) questionnaire or fill sheet that contains the question section with multiple answer choices and the question with the essay answer. In this type of measurement, formal data was collecting for respondents to answer questions. Surveyors ask questions directly to respondents, or they submitted verbally by surveyors from questions that have written. This is should do especially for respondents who have limitations, such as illiteracy, the elderly, and respondents who have difficulty reading and other conditions that make respondents unable to answer spontaneously.

The sample is a portion of the whole object that valued and considered to represent the entire population. The sample in this activity is the community that around the Kapuas Indah market, amounting to 95 people, while the sample selection technique used is Accidental Sampling. This accidental sampling technique is that anyone who meets the surveyor by chance can use, as a sample/respondent of the activity if it deemed that, the person met by chance is suitable as a source of data.

The first performed procedure in processing data from the questionnaire results was to tabulate/collect the questionnaire from the surveyor. Then, submit it to the data processor, then do the codding of each of the available multilevel answer choices, such as "very bad" answers coded number 1 , answer "slightly bad" given code number 2, answer "good enough" code number 3 , answer "good" code number 4, and answer "very good" code number 5 . After that, the interpretation of the data, namely return data that was originally in the form of numeric code to sentence form and the last to make conclusions from the relationship of these data.

Conclusion (Trend of greatest value) of Building Architecture for sellers/occupant tendencies are as follows:

a. Survey: The condition of the space occupied tends to be uncomfortable. The supporting spaces do not support selling activities, the building appearance is not good, lack of greening, the facilities and infrastructure are less comfortable and not good.

b. Interview: Room conditions are not suitable to support trade activities, there needs to be expansion, requires lighting, ventilation, warehouses, trash bins, and building security.

While the results of surveys and interviews for buyers and visitors:

a. Survey: Market corridor space conditions are not comfortable, supporting spaces do not support trade activities, the appearance of buildings is not good, greening is lacking, and facilities and infrastructure are less comfortable and not good

b. Interview: Space (corridors are inadequate), the need to activate an escalator, the need for security facilities, luggage storage, repellent parking, and adequate information services. 


\subsection{Strategies and Architectural Optimization Performance and Behavior}

Based on several assessments and descriptions of conditions presented in the previous section, here are some recommendations that can submit. Recommendations made only on parts of the assessment that have FAIR and LESS value. The "GOOD" part of the assessment assumed to reach the highest score/rating, so it is considering "reliable" according to the requirements. The "action" recommendations on the results of the assessment given in several general recommendations categories, namely:

a. Repair, it is to improve the elements condition that damaged so that they function normally and accordingly;

b. Replacement, the purpose is to replace the elements that are damaged so that they function normally and accordingly;

c. Provision, it is to provide new elements to fulfill the function/requirements;

d. Structuring, it is to reorganize/redesign existing elements to fulfill functions/requirements;

e. Addition, it is to reorganize/redesign existing elements to fulfill the function/requirements;

f. Checking/ascertaining, it is to reassure existing elements that have been functioning normally and following them to remain good under the conditions required;

g. Completing aims to add parts/overall elements required;

h. Treatment aims to do treatment of the elements that already exist.

Strategies and recommendations for building performance in the Kapuas Indah Market can see in the table below.

Table 4. Strategy and recommendations for Architectural and Behavior Performance

\begin{tabular}{|c|c|c|c|}
\hline & \multirow[t]{2}{*}{ Building Assessment } & \multicolumn{2}{|c|}{ Recomendations } \\
\hline & & Building Architecture & $\begin{array}{l}\text { Activities, Behavior, and } \\
\text { Layout } \\
\end{array}$ \\
\hline $\begin{array}{l}\text { Evaluation } \\
\text { Categories }\end{array}$ & Assessment Aspects & & \\
\hline \multirow[t]{9}{*}{ FAIR } & Ceiling Height & $\begin{array}{l}\text { The ceiling height can be added } \\
\text { above } 3 \text { meters to ensure air } \\
\text { circulation and movement } \\
\text { convenience }\end{array}$ & \\
\hline & Bathrooms and Toilets & $\begin{array}{l}\text { Providing separate bathrooms } \\
\text { between men and women; routine } \\
\text { maintenance and ensuring } \\
\text { equipment and clean water are in } \\
\text { smooth and good condition }\end{array}$ & \\
\hline & Outdoor space circulation & $\begin{array}{l}\text { Completing complementary facilities } \\
\text { / information on outer circulation; } \\
\text { routine maintenance of facilities }\end{array}$ & \\
\hline & Floor condition & Repair / replace damaged floors & \\
\hline & Wall Condition & Repair/replace damaged walls & \\
\hline & Plafond coverage condition & $\begin{array}{l}\text { Repair/replace damage plafond } \\
\text { coverage }\end{array}$ & \\
\hline & Sills condition & Repair/replace damaged sills & \\
\hline & Windows/doors fixture condition & $\begin{array}{l}\text { Repair/replace damaged windows } \\
\text { and doors fixture }\end{array}$ & \\
\hline & Roof Cover & Repair/replace damaged roof cover & \\
\hline \multirow[t]{2}{*}{ LESS } & Open Space & $\begin{array}{l}\text { Adding vegetation / parks around the } \\
\text { area up to } 30 \% \text { from coverage area }\end{array}$ & \\
\hline & Roof plate condition & Repair/replace damaged roof plate & \\
\hline FAIR & $\begin{array}{l}\text { Accession and relation of space in } \\
\text { 3rd floor }\end{array}$ & & \multirow[b]{2}{*}{$\begin{array}{l}\text { Structuring the location/ } \\
\text { type of merchandise and } \\
\text { distribution of magnet } \\
\text { activities (gathering spaces, } \\
\text { public facilities, restaurants, } \\
\text { parks, etc.) so that the } \\
\text { distribution of functions and } \\
\text { activities can be evenly } \\
\text { distributed in the building, } \\
\text { in the least distribution of } \\
\text { space and can reach all parts }\end{array}$} \\
\hline LESS & $\begin{array}{l}\text { Accession and relation of space in } \\
1 \text { st and } 2 \text { nd floor }\end{array}$ & & \\
\hline Time Period & & Short - Intermediate & Short - Intermediate \\
\hline
\end{tabular}

(Source: author) 


\section{Conclusion}

When viewed from the overall evaluation (architectural and behavior), it concluded that the "reliability" of the Kapuas Indah Market building can say to include in the FAIR category towards "LESS" in supporting trade activities and of course for human comfort in the normative predetermined building requirements. Furthermore, it is necessary to have efforts to repair and adjust so that the building can function as well as the function of the building, requirements, and of course in following the needs of the relevant parties and the development/vision-mission of the Pontianak City.

In general, the quality of the buildings has dropped so that they are not attractive. The society also tends to want the return of the "identity" of the Kapuas Indah Market, such as the escalator stairs that used to function, as well as to improve the quality of cleanliness, widening corridors, neatness, and clear information/marker systems in buildings. Expectations of the community in general, so that the Kapuas Indah Market can be more modern with good arranging shops. The community hopes will be conveying that there was a desire to re-visit the Kapuas Indah Market if a renovation made to the building. The process of "repair" (optimization) of buildings must at least comprehensively meet all building requirements, and to ensure occupants feel safe and comfortable without a single requirement not meet.

\section{Acknowledgment.}

The authors gratefully acknowledge to Public Works and Public Housing Office of Pontianak City, West Kalimantan for supporting this research.

\section{References}

Blyth, A. and A. G. (2006). Guide to Post Occupancy Evaluation. London: Higher Education Funding Council for England (HEFCE).

Fajarwati, A. N. (2016). Kajian Behavior Setting Di Pasar Tugu Simpang Lima Gumul Kediri. Jurnal Arsitektur NALARs, 15 No. 2, p. 99-108.

Gray, C. and W. H. (2001). Building Design Management (1st ed.). Oxford: Butterworth-Heinemann.

Merrit, F. S. and J. A. (1990). Building Engineering and System Design (2nd ed.). New York: Springer.

Natalia, Dita Ayu Rani, Endah Tisnawati, dan A. N. L. (2019). Evaluasi Purna Huni di Perumahan Condongcatur Ditinjau dari Aspek Penggunaan dan Perubahan Ruang. Nalars Jurnal Arsitektur, Volume 18, p.35-44.

Preiser, W.F.E., U. S. (1998). Building performance evaluation. In D. Watson, M.J. Crosbie, J.H. Callender (Eds.), Time-saver Standards (7th ed.) (7th ed). New York: McGraw Hill.

Royal Institute of British Architects. (2016). Post Occupancy Evaluation and Building Performance Evaluation Primer. London: www.architecture.com.

Setiawan, B. D. H. (2010). Arsitektur, lingkungan dan perilaku. Yogyakarta: Gadjah Mada University Press.

Siregar, Aldo Wicaksono, Jenny Ernawati, T. H. (2017). Perancangan Balai Latihan Kerja Industri Dengan Pendekatan Pola Pergerakan Pengguna. Universitas Brawijaya.

Siregar, J. P. (2014). Metodologi dasar space syntax dalam analisis konfigurasi ruang. Malang.

Syafriyani, Sangkertadi, J. O. W. (2015). Evaluasi Purna Huni (EPH) : Aspek perilaku ruang dalam SLB YPAC Manado. S.I. : Media Martasain, 12 (No.3, November 2015).

Tunstall, G. (2006). Managing the building design process (2nd ed.). https://doi.org/https://doi.org/10.4324/9780080461427 